\title{
Effects of cimetidine and ranitidine on high density lipoprotein cholesterol concentrations
}

\author{
J A WILSON, I F CRAIG
}

\begin{abstract}
To assess the effect of cimetidine and ranitidine on high density lipoprotein (HDL) cholesterol concentration two groups of eight patients with duodenal ulcer or oesophagitis matched for age, sex, and cigarette consumption were given either cimetidine $1 \mathrm{~g}$ daily or ranitidine $300 \mathrm{mg}$ daily for one month. There was no significant change in the cholesterol content of HDL and its subfraction $\mathrm{HDL}_{3}$ after treatment with ranitidine or cimetidine, or in the cholesterol content of the subfraction HDL $_{2}$ after treatment with ranitidine; the $\mathrm{HDL}_{2}$ cholesterol concentration was, however, significantly increased after treatment with cimetidine. Further studies are being undertaken to establish the mechanism of this effect.
\end{abstract}

\section{Introduction}

Cimetidine was recently reported as having caused an increase in high density lipoprotein (HDL) cholesterol concentration in a patient with type III hyperlipoproteinaemia. ${ }^{1}$ A further study showed an increase in HDL cholesterol concentrations in 10 healthy volunteers after four weeks of treatment with cimetidine $1 \mathrm{~g}$ daily. ${ }^{2}$ We examined the effect of cimetidine $1 \mathrm{~g}$ daily or ranitidine $300 \mathrm{mg}$ daily on the concentrations of cholesterol in $\mathrm{HDL}$ and its subfractions $\mathrm{HDL}_{2}$ and $\mathrm{HDL}_{3}$.

\section{Patients, methods, and results}

A fasting blood sample was withdrawn from two groups of eight patients with duodenal ulcer or oesophagitis, matched for age, sex, and cigarette consumption. Liver function, as reflected by aspartate aminotransferase and $\gamma$-glutamyltranspeptidase activities, was normal. After one month of treatment with either cimetidine $1 \mathrm{~g}$ daily or ranitidine $300 \mathrm{mg}$ daily, allocated in random fashion, a further

Ninewells Hospital, Dundee DD2 1UB

I A WILSON, MRCP, senior registrar

I F CRAIG, PHD, medical student

Correspondence to: Dr J A Wilson.

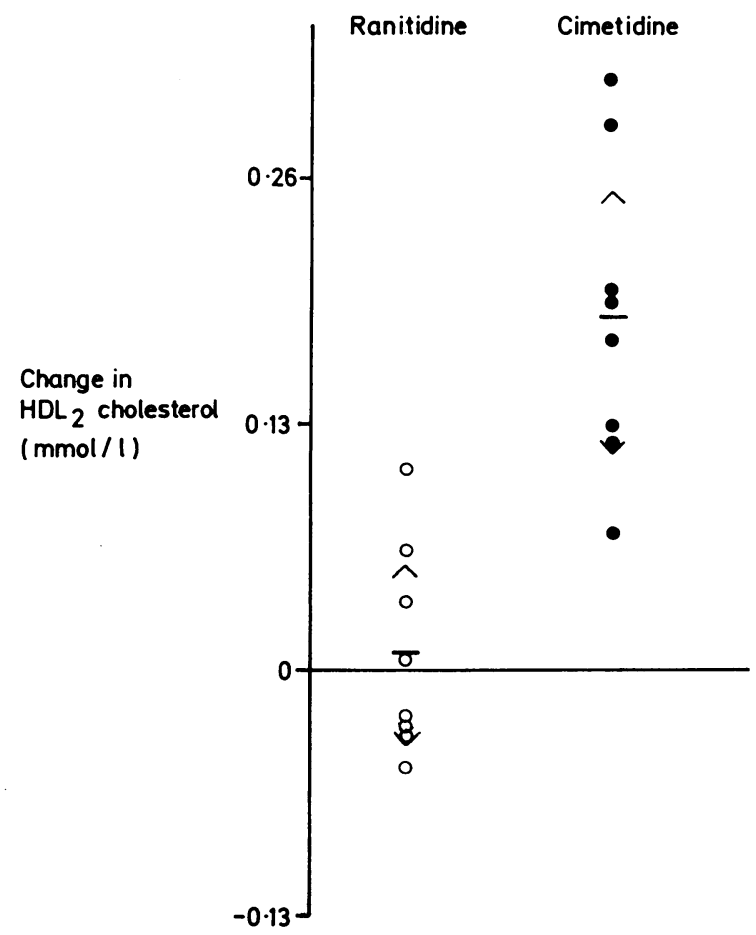

Individual changes in $\mathrm{HDL}_{2}$ cholesterol concentration after one month's treatment in eight patients given cimetidine and eight given ranitidine. Horizontal bars indicate mean values; $95 \%$ confidence limits are also shown.

Conversion: SI to traditional units-Cholesterol: $1 \mathrm{mmol} / 1 \approx 38.6 \mathrm{mg} / 100$ $\mathrm{ml}$

fasting sample was withdrawn. On each occasion the plasma was separated immediately and stored at $4^{\circ} \mathrm{C}$ and, within four days, HDL was precipitated sequentially with heparin-manganese and dextran sulphate of molecular weight 15000 daltons, which isolated $\mathrm{HDL}_{\mathrm{p}}$ and $\mathrm{HDL}_{\mathrm{s}}$ (corresponding to $\mathrm{HDL}_{2}$ and $\left.\mathrm{HDL}_{3}\right)^{3}$ The cholesterol content of $\mathrm{HDL}, \mathrm{HDL}_{2}$, and $\mathrm{HDL}_{3}$ was measured with a commercially available kit containing cholesterol oxidase and cholesterol esterase. Statistical analysis was undertaken with the Wilcoxon ranked sum test.

The table shows the results. Concentrations of $\mathrm{HDL}, \mathrm{HDL}_{2}$, and $\mathrm{HDL}_{3}$ cholesterol were not significantly different after treatment 
Median HDL cholesterol concentrations (and ranges) (mmol/l) before and after treatment with cimetidine or ranitidine

\begin{tabular}{|c|c|c|c|}
\hline & Before treatment & After treatment & Significance \\
\hline $\begin{array}{l}\text { HDL cholesterol: } \\
\text { Cimetidine } \\
\text { Ranitidine }\end{array}$ & $\begin{array}{l}1.24(0.91-1.75) \\
1.08(0.85-2.20)\end{array}$ & $\begin{array}{l}1.39(0.87-2 \cdot 19) \\
1.07(0.84-2 \cdot 23)\end{array}$ & $\begin{array}{l}\text { NS } \\
\text { NS }\end{array}$ \\
\hline $\begin{array}{l}\mathrm{HDL}_{2} \text { cholesterol: } \\
\text { Cimetidine } \\
\text { Ranitidine }\end{array}$ & $\begin{array}{l}0.21(0.04-0.57) \\
0.29(0.06-1.24)\end{array}$ & $\begin{array}{l}0.42(0.11-0.85) \\
0.26(0.12-1.34)\end{array}$ & $\begin{array}{c}\mathrm{p}<0.01 \\
\text { NS }\end{array}$ \\
\hline $\begin{array}{l}\text { HDL } L_{3} \text { cholesterol: } \\
\text { Cimetidine } \\
\text { Ranitidine }\end{array}$ & $\begin{array}{l}0.97(0.85-1.18) \\
0.81(0.63-0.96)\end{array}$ & $\begin{array}{l}0.90(0 \cdot 76-1 \cdot 14) \\
0.83(0.66-1 \cdot 01)\end{array}$ & $\begin{array}{l}\text { NS } \\
\text { NS }\end{array}$ \\
\hline
\end{tabular}

Conversion: $S I$ to traditional units-Cholesterol: $1 \mathrm{mmol} / 1 \approx 38.6 \mathrm{mg} / 100 \mathrm{ml}$.

with ranitidine, and concentrations of $\mathrm{HDL}$ and $\mathrm{HDL}_{3}$ cholesterol were not significantly different after treatment with cimetidine. $\mathrm{HDL}_{2}$ cholesterol concentrations were significantly raised, however, after treatment with cimetidine $(\mathrm{p}<0.01)$ (figure).

\section{Discussion}

An increase in $\mathrm{HDL}_{2}$ cholesterol can be explained either by an increase in the secretion of new particles into this density range or by changes in metabolism leading to accumulation of $\mathrm{HDL}_{2}$ without the need for de novo synthesis. We suggest two possible mechanisms: firstly, cimetidine has antiandrogenic properties, and HDL is related to testosterone concentrations ${ }^{4}$; secondly, cimetidine might activate lipoprotein lipase or lecithin cholesterol acyltransferase, both of which play a part in converting $\mathrm{HDL}_{3}$ to $\mathrm{HDL}_{2}$. The true explanation for these changes remains unclear, but, in view of the widely reported inverse relation between $\mathrm{HDL}_{2}$ concentrations and accelerated ischaemic heart disease, this finding is potentially useful. Further studies are being undertaken to examine the mechanism of this effect.

\section{References}

1 Miller NE, Lewis B. Cimetidine and HDL cholesterol. Lancet 1983; ; 529. Bolton $\mathrm{CH}$, Daneshmend TK, Ene MD, et al. The effects of cimetidine on serum and lipoprotein lipids in normal subjects. Br f Clin Pharmacol 1983;15:152. Gidez LI, Miller GJ, Burstein M, et al. Separation and quantitation of sub classes of human plasma HDL by a simple precipitation procedure. $\mathcal{F}$ Lipid Res $1982 ; 23: 1206$

4 Furman RH, Alaupovic PJ, Howard RP. Effects of androgens and oestrogens on serum lipids and the composition of serum lipoproteins in normolipaemia and
hyperlipaemic states. Prog Biochem Pharmacol 1967;2:215-49.

(Accepted 13 December 1984)

\title{
Seroepidemiology of HTLV-III antibodies in a remote population of eastern Zaire
}

\author{
ROBERT J BIGGAR， MADS MELBYE， LUC KESTENS，MARC DE FEYTER，CARL SAXINGER, \\ ANNE J BODNER, L PALUKO, WILLIAM A BLATTNER, PAUL L GIGASE
}

\begin{abstract}
A human retrovirus-human $\mathrm{T}$ cell lymphotropic virusIII (HTLV-III)-has recently emerged as the probable cause of acquired immunodeficiency syndrome (AIDS). In May 1984, 250 outpatients at a hospital in a remote area of eastern Zaire were surveyed for AIDS type illnesses and the prevalence of antibodies against HTLV-III determined by an enzyme linked immunosorbent assay using disrupted whole HTLV-III virus as the antigen. No clinical cases of AIDS were diagnosed among these patients.
\end{abstract}

National Cancer Institute, Bethesda, Maryland, USA

ROBERT J BIGGAR, MD, medical epidemiologist

CARL SAXINGER, PHD, microbiologist

WILLIAM A BLATTNER, MD, chief of family studies section

Institute of Cancer Research, Aarhus, Denmark

MADS MELBYE, MD, medical staff fellow

Institute of Tropical Medicine, Antwerp, Belgium

LUC KESTENS, BSC, biologist

PAUL L GIGASE, MD, head of department of pathology

FOMULAC Hospital, Katana, Kivu District, Zaire

MARC DE FEYTER, MD, chief physician

L PALUKO, MD, internist

Biotech Research Laboratories Inc, Rockville, Maryland, USA ANNE J BODNER, PHD, chief of serotesting

Correspondence to: Dr R J Biggar, Landow Building 3C19, Bethesda, Maryland, USA, 20205.
Overall, $31(12.4 \%)$ had clearly positive ratios $(\geqslant 5 \cdot 0)$ and a further $30(12 \cdot 0 \%)$ had borderline ratios (3.0- $<5 \cdot 0)$. Western blots of serum samples from subjects with antibodies yielded bands consistent with HTLV-III as found in American patients with AIDS and members of groups at risk of AIDS. The prevalence of antibody was highest in childhood ( $p=0.02)$; among adults prevalence rose slightly with age. HTLV-III antibodies were more common among the uneducated $(p=0.006)$, agricultural workers $(p=0.03)$, and rural residents $(p=0.06)$, but the Western blot bands were generally weak in this group. By contrast, one urban resident had strong bands.

The relatively high prevalence of antibodies among the rural poor in this area of Zaire suggests that HTLVIII or a closely related, cross reactive virus may be endemic in the region. A different natural history of infection, perhaps in childhood, may also explain the findings.

\section{Introduction}

Investigators have recently described a retrovirus that appears to be a causative for acquired immunodeficiency syndrome (AIDS). ${ }^{1-4}$ This agent, a member of the human $T$ cell lymphotropic virus (HTLV) family, has repeatedly been isolated from American and European patients with AIDS and subjects at risk of AIDS, most of whom also had detectable antibody against the agent. ${ }^{56}$ Prospective studies have confirmed that those with antibodies are more likely to develop AIDS. ${ }^{78}$ By contrast, fewer than $1 \%$ of healthy American blood donors have antibodies to the agent. ${ }^{5} 8 \mathrm{a}$

AIDS has also been described in Africans ${ }^{9-13}$ and in Europeans who had a history of travel in Africa but no other risk 